\title{
Article \\ Effects of Short-Term Rice Straw Return on the Soil Microbial Community
}

\author{
Enze Wang ${ }^{1}\left(\mathbb{D}\right.$, Xiaolong Lin ${ }^{1,2}$, Lei Tian ${ }^{1}$, Xinguang Wang ${ }^{3}$, Li Ji ${ }^{1,2}$, Feng Jin ${ }^{4, *}$ and Chunjie Tian ${ }^{1, *}$ (1) \\ 1 Northeast Institute of Geography and Agroecology, Chinese Academy of Sciences, Changchun 130102, China; \\ wangenze@iga.ac.cn (E.W.); linxiaolong@iga.ac.cn (X.L.); tianlei@iga.ac.cn (L.T.); jili@iga.ac.cn (L.J.) \\ 2 University of Chinese Academy of Sciences, Beijing 100049, China \\ 3 College of Biotechnology, Tianjin University of Science and Technology, Tianjin 300457, China; \\ wangxg1997202106@163.com \\ 4 Faculty of Agriculture, Jilin Agricultural University, Changchun 130102, China \\ * $\quad$ Correspondence: jinfeng@jlau.edu.cn (F.J.); tiancj@iga.ac.cn (C.T.); Tel.: +86-451-85542315 (C.T.)
}

Citation: Wang, E.; Lin, X.; Tian, L.; Wang, X.; Ji, L.; Jin, F.; Tian, C. Effects of Short-Term Rice Straw Return on the Soil Microbial Community. Agriculture 2021, 11, 561. https:// doi.org/10.3390/agriculture11060561

Academic Editor: Cristina Abbate

Received: 1 June 2021

Accepted: 16 June 2021

Published: 18 June 2021

Publisher's Note: MDPI stays neutral with regard to jurisdictional claims in published maps and institutional affiliations.

Copyright: (c) 2021 by the authors. Licensee MDPI, Basel, Switzerland. This article is an open access article distributed under the terms and conditions of the Creative Commons Attribution (CC BY) license (https:// creativecommons.org/licenses/by/ $4.0 /)$.

\begin{abstract}
Rice straw is a byproduct of agricultural production and an important agricultural resource. However, rice straw has not yet been effectively used, and incorrect treatment methods (such as burning in the field) can cause serious damage to the environment. Studies have shown that straw returning is beneficial to soil, but there have been few studies focused on the effect of the amount of short-term straw returned on the soil microbial community. This study evaluates $0 \%, 50 \%, 75 \%$, and $100 \%$ rice straw returned to the field on whether returning different amounts of straw in the short term would affect the diversity and composition of the soil microbial community and the correlation between bacteria and fungi. The results show that the amount of straw returned to the field is the main factor that triggers the changes in the abundance and composition of the microbial community in the paddy soil. A small amount of added straw ( $\leq 50 \%$ straw added) mainly affects the composition of the bacterial community, while a larger amount of added straw $(>50 \%$ straw added) mainly affects the composition of the fungal community. Returning a large amount of straw increases the microbial abundance related to carbon and iron cycles in the paddy soil, thus promoting the carbon and iron cycle processes to a certain extent. In addition, network analysis shows that returning a large amount of straw also increases the complexity of the microbial network, which may encourage more microbes to be niche-sharing and comprehensively improve the ecological environment of paddy soil. This study may provide some useful guidance for rice straw returning in northeast China.
\end{abstract}

Keywords: straw returning; microbial community; network analysis; Northeast of China

\section{Introduction}

Mollisols, also known as black soil, are one of the most precious soil resources in China [1,2], and original black soil is fertile and rich in organic matter. However, due to long-term anthropogenic and destructive cultivation, the organic matter content in the topsoil of black soil has decreased rapidly [3], leading to soil degradation [1], which has seriously affected the sustainability of agricultural development in the black soil area. Crop straw contains a lot of organic matter and nutrient elements that are essential for plant growth [4]. Returning straw to the field can input a large amount of organic matter into the soil [5], and in this process, a series of complex biochemical reactions would occur in the soil system, such as the mineralization of nitrogen and the priming effect from the decomposition of organic matter, which can significantly improve soil quality $[6,7]$.

As a traditional agricultural country, China produces about 1.04 billion metric tons of crop straw every year [8]. Straw returning to fields is increasingly recommended by researchers based on its beneficial effects on crop yield and soil quality [9-11]. Microorganisms play a leading role in crop straw decomposition. When the appropriate amount 
of crop straw is incorporated into the soil, the nutrient content in the soil will increase to promote the growth of soil microorganisms [12]. However, microbial processes for crop straw decomposition are affected by the straw quality and other abiotic factors influencing soil microbial activity and community composition, such as soil type and temperature, nitrogen $(\mathrm{N})$ and phosphorus $(\mathrm{P})$ levels, $\mathrm{pH}$, and the $\mathrm{C} / \mathrm{N}$ ratio [13-17]. Therefore, microbial activities and communities will have different characteristics in different areas when the straw is returned to the field. Northeast China is a high-latitude region with obvious seasonality and is highly sensitive to climate change. The long-term low-temperature environment has seriously influenced microbial activity and community composition [18] Most recent research has focused on the effect of straw returning on the physical and chemical properties of the soil, while studies focusing on the ecological effects of returned straw on the soil microbial community are relatively rare.

Soil types directly affect the composition of soil microorganisms. The flood-anddrain cycles that occur in the production of rice create shifts in reduced and oxidized environments, providing a suitable growth environment for a wide variety of microbes. Therefore, there are significant differences in microbial communities between upland and paddy fields [19-21]. For example, the abundance of bacteria in paddy soil is much higher than that in upland soil, especially nitrogen-fixing cyanobacteria. However, the abundance of fungi and actinomycetes in paddy fields is relatively low compared to upland soil [22]. Nitrification and denitrification in paddy soil regulate the ratio of carbon to nitrogen in the soil, thus having a certain positive effect on the decomposition process of rice straw [23-25].

In addition, the amount of straw returned to the field also affects the composition and diversity of soil microorganisms. Yang et al. found that straw returning altered the soil microbial community composition and increased the functional diversity [26]. Zhao et al. found that small amounts $\left(\leq 4500 \mathrm{~kg} \cdot \mathrm{ha}^{-1}\right)$ of long-term straw incorporation did not affect the soil microbial community, while the incorporation of large quantities $\left(9000 \mathrm{~kg} \cdot \mathrm{ha}^{-1}\right)$ of straw significantly altered the soil microbial community structure [27]. In this study, we aim to explore the effects of the quantity of rice straw returned on the diversity and co-occurrence pattern of soil microbial communities in northeast China. The findings may provide a reference for the practice of straw returning in northeast China.

\section{Materials and Methods}

\subsection{Site Description}

The study was carried out in Wanchang County, Jilin City, Jilin Province, China $\left(43^{\circ} 73^{\prime}\right.$ $\mathrm{N}, 125^{\circ} 89^{\prime} \mathrm{E}$ ). This site belongs to the continental dry-cold monsoon climate in the northern temperate zone, with an average annual temperature of $5.3^{\circ} \mathrm{C}$ and an annual rainfall of approximately $677.4 \mathrm{~mm}$. The precipitation is concentrated from June to August. The soil type in this area is Mollisol with a clay soil quality; the basic physical and chemical properties of the soil are as follows: The soil organic matter content is $13.34 \mathrm{~g} \cdot \mathrm{kg}^{-1}$, the total nitrogen content is $0.51 \mathrm{mg} \cdot \mathrm{kg}^{-1}$, the available phosphorus content is $5.83 \mathrm{mg} \cdot \mathrm{kg}^{-1}$, the available potassium content is $162.82 \mathrm{mg} \cdot \mathrm{kg}^{-1}$, and the soil $\mathrm{pH}$ is 6.73 .

\subsection{Experimental Design}

A randomized complete block designed field experiment was used to test the effect of four paddy straw treatments ( $0 \%$ straw returned, $50 \%$ returned [low level], $75 \%$ returned [middle level], and all aboveground straw returned [high level]) on soil microbial properties. The experiment had three blocks, and each block contained four paddy fields (12 total fields). They were then randomly assigned with one paddy straw treatment in October 2017. Fields were 300 square meters each ( $20 \mathrm{~m}$ long and $15 \mathrm{~m}$ wide). The straw used for returning to the paddy field was the rice variety straw Ji Hong 9, with a high yield and stress resistance (The carbon-nitrogen ratio of rice straw is 55:1). The specific process of returning straw to the paddy field was as follows: After the rice matured, the rice straw was cut into 5-10 cm segments and evenly covered on the surface of the farmland. Then, the mulched straw was rotated into the soil by a rotary tiller, and the returned depth was 
0-20 cm. Rice was planted on the ground, and machine transplanting (sowing density was $30 \times 13 \mathrm{~cm}$ ) was performed. There was no other soil disturbance except straw returning and rice planting. Conventional fertilization (Urea $325 \mathrm{~kg} \cdot \mathrm{hm}^{-1}$, diamine $120 \mathrm{~kg} \cdot \mathrm{hm}{ }^{-1}$, potassium chloride $120 \mathrm{~kg} \cdot \mathrm{hm}^{-1}$ ) and water management were used for rice planting. The paddy field was irrigated on 1 May, and the irrigation was cut off on September 10. The experiment was carried out for two years. In November 2019, the soil samples were collected from the paddy soil $(0-20 \mathrm{~cm})$. The soil extractor bit was an undisturbed soil extractor with a length of $20 \mathrm{~cm}$ and a diameter of $38 \mathrm{~mm}$. Five drills of soil were taken from each field, evenly mixed into a sample, and then stored in a refrigerator at $4{ }^{\circ} \mathrm{C}$. The samples for soil DNA extraction were stored in a refrigerator at $-80^{\circ} \mathrm{C}$.

\subsection{DNA Extraction and High-Throughput Sequencing}

Soil microbial DNA was extracted from each sample $(0.5 \mathrm{~g})$ using a Fast DNA SPIN Kit (MP Bio Laboratories, Carlsbad, CA, USA) according to the manufacturer's instructions. The obtained DNA was dissolved in sterile distilled water, and the quality and quantity of the DNA were checked by a NanoDrop 2000 (Thermo Scientific, Schwerte, Germany). For bacteria, the V3-V4 region of the $16 \mathrm{~S}$ rRNA gene (the sequences of the primers used were $341 \mathrm{~F}$ $5^{\prime}$-ACTCCTACGGGAGGCAGCA-3' and 785R $5^{\prime}$-GGACTACHVGGGTWTCTAAT-3') was amplified to determine the composition of the bacterial community [28]. For fungi, the ITS1 region (the sequences of the primers used were ITS1F $5^{\prime}$-CTTGGTCATTTAGAGGAAGTAA$3^{\prime}$ and ITS2R $5^{\prime}$-GCTGCGTTCTTCATCGATGC-3') was amplified to determine the composition of the fungal community [29-31]. Finally, PCR amplicons were used to construct the library, which was sequenced by the Illumina NovaSeq platform (Illumina, San Diego, CA, USA).

QIIME2 (https:/ / view.qiime2.org/, accessed on 30 January 2020) was used to analyze the raw sequencing data [32]. For bacterial data, the vsearch plug-in was used to merge the paired sequences, then the quality filter plug-in was used. The obtained effective sequencing was used to remove the redundancy of bacterial sequences to obtain representative sequences by the deblur plug-in; for fungi, the data2 plug-in was used to denoise the data and obtain the representative sequence and redundant sequence feature table. Then, a phylogenetic plug-in was used to construct a phylogenetic tree using representative sequences. The diversity plug-in was used to calculate the core diversity of the data, including the Shannon index, Bray-Curtis clustering, the UniFrac distance matrix, etc. Based on the representative sequence, the bacterial taxonomy refers to the Greengene database gg_13_8 with a $99 \%$ similarity, while the fungal taxonomy refers to the UNITE database version 7.1 with a $97 \%$ sequence similarity using the feature-classifier plug-in. Usearch v.10 was used to identify representative operational taxonomic units (OTUs) [33].

\subsection{Data Analysis}

Principal component analysis (PCA) was carried out according to the distance matrix of Bray-Curtis clustering strains through the PCoA function of the vegan package in $\mathrm{R}$ version 4.0.2 to represent the clustering of each group of samples [34,35]. The coinertia function of the ade4 package in $R$ version 4.0.2 was used to calculate and plot the interaction between bacteria and fungi when different amounts of straw were returned to the field [36]. To prove the correlation between bacterial and fungal communities, Gephi 0.9.2 was used to analyze the Spearman correlation coefficients of total OTUs ( $|\mathrm{R}| \geq 0.8, p<0.05)$, and the values of nodes and edges were calculated $[37,38]$. The correlation coefficient was calculated using the corr.test function in R software version 4.0.2 and the psych software package [37,39].

\section{Results}

\subsection{Alpha Diversity of the Microbial Communities}

According to the results of the high-throughput sequencing data, a total of $1,883,851$ reads were obtained for bacteria, and 1,695,371 reads were obtained for fungi from the samples 
after quality filtering and resampling. A total of 14,628 bacterial OTUs were obtained, while a total of 1246 fungal OTUs were obtained from the samples. The numbers of shared bacterial- and fungal-related OTUs were 6492 (44.38\% of total) and 432 (34.67\% of total), respectively. The rarefication curves of all the samples showed that the curves were saturated (Figure A1), indicating that the sequencing data were sufficient to represent the species obtained.

The alpha diversity indices (Chao1, ACE, Shannon, and Simpson indices) of the bacterial and fungal communities were calculated, as shown in Table 1. The results showed no significant difference among the treatments in terms of bacterial alpha diversity (Chao1, ACE, Simpson, and Shannon indices). However, the amount of straw returned to the paddy field significantly affected the richness of the fungal community. The Chao1 and ACE indices for the $75 \%$ straw returning and $100 \%$ straw returning treatments were significantly lower than those of the $0 \%$ straw returning treatment, while there were no significant differences among the treatments in terms of Shannon and Simpson index values. In addition, we also found that the number of fungal OTUs observed in the straw returning treatment was significantly lower than that of the treatment without straw returning, but there were no significant differences among the treatments in terms of bacterial OTUs. The results showed that the amount of straw returned to the paddy field had no influence on the bacterial alpha diversity, while increasing the amount of straw returned to the paddy field caused the richness of the fungal community and the number of OTUs to significantly decrease.

Table 1. Effects of rice straw addition on the alpha diversity indices of the bacterial and fungal communities.

\begin{tabular}{|c|c|c|c|c|c|c|}
\hline & Straw Addition & Chao 1 & $\mathrm{ACE}$ & Simpson & Shannon & $\begin{array}{c}\text { The Number } \\
\text { of OTUs }\end{array}$ \\
\hline \multirow{4}{*}{ Bacteria } & $0 \%$ & $4097.23 \pm 19.13 \mathrm{a}$ & $4023.71 \pm 153.68 \mathrm{a}$ & $0.9981 \pm 0.002 \mathrm{a}$ & $10.48 \pm 0.04 \mathrm{a}$ & $3396.67 \pm 32.25 a$ \\
\hline & $50 \%$ & $3978.75 \pm 151.81 \mathrm{a}$ & $4121.79 \pm 98.71 \mathrm{a}$ & $0.9977 \pm 0.003 \mathrm{a}$ & $10.47 \pm 0.10 \mathrm{a}$ & $3355.00 \pm 118.25 \mathrm{a}$ \\
\hline & $75 \%$ & $4080.96 \pm 98.50 \mathrm{a}$ & $3908.46 \pm 65.73 a$ & $0.9969 \pm 0.004 \mathrm{a}$ & $10.39 \pm 0.02 \mathrm{a}$ & $3390.67 \pm 31.20 \mathrm{a}$ \\
\hline & $100 \%$ & $3862.76 \pm 69.83 \mathrm{a}$ & $4135.83 \pm 22.97 a$ & $0.9970 \pm 0.009 a$ & $10.35 \pm 0.08 \mathrm{a}$ & $3288.00 \pm 30.34 \mathrm{a}$ \\
\hline \multirow{4}{*}{ Fungi } & $0 \%$ & $1041.67 \pm 62.40 \mathrm{a}$ & $1041.82 \pm 62.35 \mathrm{a}$ & $0.9667 \pm 0.002 \mathrm{a}$ & $6.45 \pm 0.16 \mathrm{a}$ & $664.33 \pm 54.48 \mathrm{a}$ \\
\hline & $50 \%$ & $830.33 \pm 52.09 \mathrm{ab}$ & $830.33 \pm 52.09 \mathrm{ab}$ & $0.9457 \pm 0.023 \mathrm{a}$ & $5.73 \pm 0.40 \mathrm{a}$ & $480.67 \pm 36.23 b$ \\
\hline & $75 \%$ & $776.67 \pm 56.04 \mathrm{~b}$ & $776.67 \pm 56.04 b$ & $0.9107 \pm 0.028 \mathrm{a}$ & $5.16 \pm 0.32 \mathrm{a}$ & $470.33 \pm 45.32 \mathrm{~b}$ \\
\hline & $100 \%$ & $781.33 \pm 161.40 \mathrm{~b}$ & $781.50 \pm 161.51 \mathrm{~b}$ & $0.8656 \pm 0.093 \mathrm{a}$ & $5.26 \pm 0.93 \mathrm{a}$ & $484.00 \pm 113.53 \mathrm{~b}$ \\
\hline
\end{tabular}

Note: One-way analysis of variance was used to test for significant differences in the diversity indices of fungi and bacteria, and the number of operational taxonomic units (OTUs) observed in paddy soil under different straw returning amounts. The significance of post hoc pairwise comparisons was determined using Tukey's LSD test with a significance level of 0.05 . Additionally, analyses were performed using the software package IBM SPSS statistics 20.0 for Windows. We repeated each treatment three times $(n=3)$. For each treatment, means in the same column with different lowercase letters differ significantly $(p<0.05)$.

\subsection{Effect of Rice Straw Returning on Bacterial and Fungal Beta Diversity}

Based on the unweighted UniFrac distance (Figure 1), we found that the composition of soil communities varied among different treatments $(p<0.001)$. Specifically, relatively unique bacterial communities were observed for the control field ( $0 \%$ straw returning) and the field with a low level of straw addition (50\% straw returning). The bacterial communities of fields treated with middle and high levels of straw additions $(75 \%$ and $100 \%$ straw returning) were relatively similar to each other, but differed from those fields treated with smaller straw additions (Figure 1A). The amount of straw returned to the paddy fields had different effects on the fungal community compared with the bacterial community. We found that the fungal communities of medium and high levels of straw return (50\% and $75 \%$ straw return) were relatively similar to the fungal communities without straw return $(0 \%$ straw return). However, there were specific differences between the treatments of middle and high levels of straw return. Additionally, the fungal community of fields treated with $100 \%$ rice straw differed from those of the other three treatments (Figure 1B). The results showed that the composition of the bacterial community was more likely to be affected by a low level of straw addition, while the composition of the fungal community was more likely affected by a high level of straw addition. 

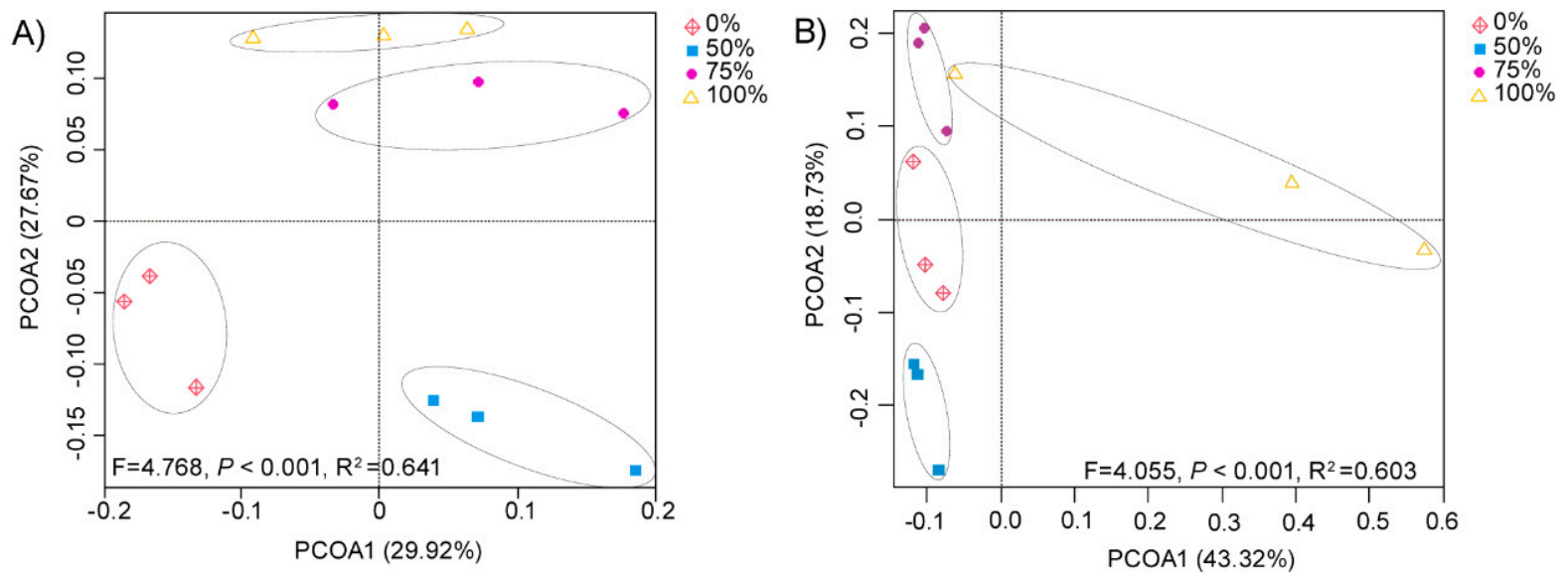

Figure 1. Effect of straw addition on bacterial and fungal beta diversity. Principal coordinate analysis (PCoA) of bacterial (A) ( $p$ values $\left.<0.001, \mathrm{R}^{2}=0.641\right)$ and fungal (B) ( $p$ values $<0.001, \mathrm{R}^{2}=0.603$ ) communities for fields given $0 \%, 50 \%, 75 \%$, and $100 \%$ rice straw returning treatments based on the unweighted UniFradistance of bacterial and fungal communities. The first and second principal components of the PCoA of the bacterial community explained $29.92 \%$ and $27.67 \%$ of the communities, respectively. The first and second principal components of the PCoA of the fungal community explained $43.32 \%$ and $18.73 \%$ of the communities, respectively. Each treatment had three replicates $(n=3)$.

\subsection{Compositional Characteristics of Soil Microbial Communities under Different Straw Addition Levels}

3.3.1. Compositional Characteristics of Soil Bacterial Communities under Different Straw Addition Levels

The relative abundances of the bacteria phyla at different levels of straw addition were shown in Figure 2A. The main bacterial phyla were Proteobacteria (33.75-45.36\%), Chloroflexi (12.27-20.47\%), Actinobacteria (11.15-17.55\%), Acidobacteria (10.64-14.19\%), Gemmatimonadetes (2.91-5.47\%), Nitrospirae (1.55-4.19\%), and Bacteroidetes (2.84-5.76\%). We found that the composition of the bacterial communities in the paddy soil was affected by the addition of straw and that different amounts of straw had different effects on the composition of the bacterial communities (Table 2). For example, the relative abundance of Bacteroidetes increased significantly as the amount of straw added increased. In addition, Acidobacteria, Cyanobacteria, and Nitrosoirae were more abundant in the treatments involving small amounts of straw additions ( $\leq 50 \%$ straw returning); Proteobacteria was the most abundant in the treatments involving high amounts of straw additions; and Gemmatimonadetes was the most abundant in the treatments with no straw addition.

We also tested the effect of straw treatments on the abundance of common $(\geq 1 \%)$ bacteria genera (Table 3). The relative abundance of Flavobacterium in the phylum Bacteroidetes increased significantly after the addition of straw. In the treatment without straw addition, the relative abundance of Flavobacterium was only $0.45 \%$, while the relative abundance of Flavobacterium increased to $2.02-2.62 \%$ after the addition of straw. The relative abundances of Candidatussolibacter (2.54-2.87\%) and Candidatuskoribacter (2.06-2.56\%), in the phylum Acidobacteria, tended to be lower in fields with large straw additions $(>50 \%$ straw returning) than fields with low straw additions $(3.37-4.36 \%$ and $3.17-3.81 \%$, respectively). The relative abundance of Nitroospira in the phylum Nitrosoirae decreased with the addition of straw (decreased by 0.97-1.21\%). The changes in the Proteobacteria sub-group were more complicated; for example, the relative abundance of Geobacter, Pseudomonas, and Crenohrix in the treatment involving a high level of straw addition increased significantly (increased by $5.10 \%, 2.09 \%$, and $5.24 \%$, respectively). 

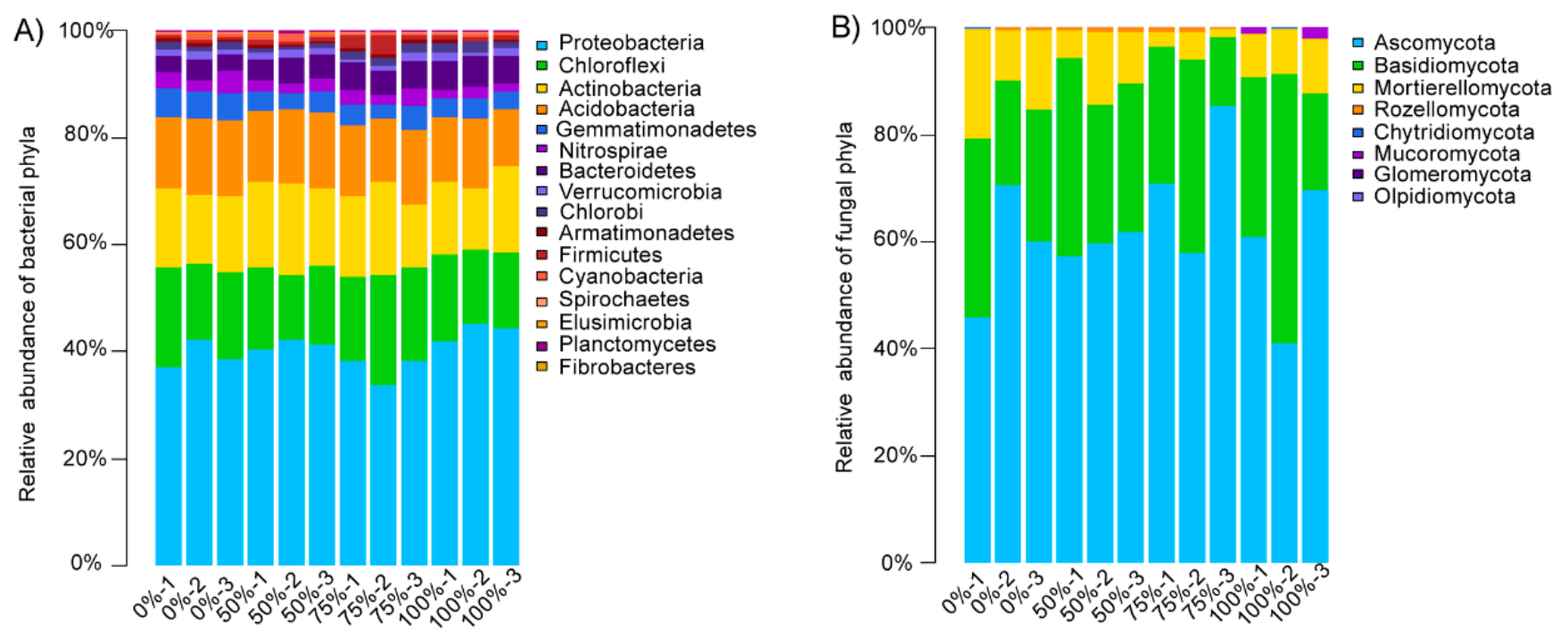

Figure 2. The relative abundance of the bacterial (A) and fungal (B) phyla at different levels of straw addition. The relative abundance was calculated as the average of the replicates for each group.

Table 2. Relative abundance of bacteria and fungi at the phylum level in paddy soil with different levels of straw additions.

\begin{tabular}{|c|c|c|c|c|c|}
\hline Kingdom & Phyla & $\begin{array}{l}0 \% \text { Straw } \\
\text { Returning }\end{array}$ & $\begin{array}{l}50 \% \text { Straw } \\
\text { Returning }\end{array}$ & $\begin{array}{l}75 \% \text { Straw } \\
\text { Returning }\end{array}$ & $\begin{array}{c}\text { 100\% Straw } \\
\text { Returning }\end{array}$ \\
\hline \multirow{16}{*}{ Bacteria } & Acidobacteria & $0.1387 \pm 0.0045 \mathrm{a}$ & $0.1374 \pm 0.0025 \mathrm{a}$ & $0.1284 \pm 0.0091 \mathrm{ab}$ & $0.119 \pm 0.01 \mathrm{~b}$ \\
\hline & Actinobacteria & $0.1393 \pm 0.0066 \mathrm{a}$ & $0.1582 \pm 0.0102 \mathrm{a}$ & $0.1479 \pm 0.0234 \mathrm{a}$ & $0.1367 \pm 0.0201 \mathrm{a}$ \\
\hline & Armatimonadetes & $0.005 \pm 0.0014 \mathrm{a}$ & $0.0045 \pm 0.0008 \mathrm{a}$ & $0.0053 \pm 0.0014 \mathrm{a}$ & $0.0035 \pm 0.001 \mathrm{a}$ \\
\hline & Bacteroidetes & $0.0318 \pm 0.0039 c$ & $0.0448 \pm 0.0043 b$ & $0.0489 \pm 0.0035 \mathrm{ab}$ & $0.055 \pm 0.0021 \mathrm{a}$ \\
\hline & Chlorobi & $0.0134 \pm 0.002 \mathrm{a}$ & $0.0083 \pm 0.0012 b$ & $0.0166 \pm 0.0021 \mathrm{a}$ & $0.017 \pm 0.0022 \mathrm{a}$ \\
\hline & Chloroflexi & $0.1641 \pm 0.0197 \mathrm{ab}$ & $0.1402 \pm 0.0126 b$ & $0.1798 \pm 0.0191 \mathrm{a}$ & $0.1482 \pm 0.0101 \mathrm{ab}$ \\
\hline & Cyanobacteria & $0.0082 \pm 0.0037 \mathrm{ab}$ & $0.0105 \pm 0.0027 \mathrm{a}$ & $0.0035 \pm 0.0009 \mathrm{~b}$ & $0.0036 \pm 0.0003 b$ \\
\hline & Elusimicrobia & $0.0016 \pm 0.0002 \mathrm{a}$ & $0.0013 \pm 0.0003 \mathrm{a}$ & $0.0012 \pm 0.0004 \mathrm{a}$ & $0.0012 \pm 0.0002 \mathrm{a}$ \\
\hline & Fibrobacteres & $0.0001 \pm 0.0001 \mathrm{~b}$ & $0.0004 \pm 0.0001 \mathrm{a}$ & $0.0002 \pm 0 \mathrm{~b}$ & $0.0003 \pm 0.0001 \mathrm{~b}$ \\
\hline & Firmicutes & $0.0052 \pm 0.0004 \mathrm{~b}$ & $0.0075 \pm 0.0009 \mathrm{~b}$ & $0.024 \pm 0.0112 \mathrm{a}$ & $0.0096 \pm 0.0004 b$ \\
\hline & Gemmatimonadetes & $0.0523 \pm 0.0021 \mathrm{a}$ & $0.0357 \pm 0.0041 \mathrm{~b}$ & $0.0372 \pm 0.0062 \mathrm{~b}$ & $0.0349 \pm 0.0028 b$ \\
\hline & Nitrospirae & $0.0316 \pm 0.0079 \mathrm{a}$ & $0.0207 \pm 0.0032 \mathrm{ab}$ & $0.0261 \pm 0.0062 \mathrm{ab}$ & $0.0176 \pm 0.0024 b$ \\
\hline & Planctomycetes & $0.0017 \pm 0.0002 b$ & $0.0028 \pm 0.0007 \mathrm{a}$ & $0.0012 \pm 0.0002 b$ & $0.0011 \pm 0.0002 \mathrm{~b}$ \\
\hline & Proteobacteria & $0.3929 \pm 0.0223 b c$ & $0.4137 \pm 0.0063 \mathrm{ab}$ & $0.3675 \pm 0.0213 c$ & $0.4382 \pm 0.0147 \mathrm{a}$ \\
\hline & Spirochaetes & $0.0016 \pm 0.0001 \mathrm{a}$ & $0.0014 \pm 0.0004 \mathrm{a}$ & $0.0018 \pm 0.0003 \mathrm{a}$ & $0.0022 \pm 0.0008 \mathrm{a}$ \\
\hline & Verrucomicrobia & $0.0125 \pm 0.0029 \mathrm{a}$ & $0.0127 \pm 0.001 \mathrm{a}$ & $0.0104 \pm 0.0037 \mathrm{a}$ & $0.0119 \pm 0.0036 \mathrm{a}$ \\
\hline \multirow{6}{*}{ Fungi } & Ascomycota & $0.5885 \pm 0.1015 a$ & $0.5954 \pm 0.0183 a$ & $0.7125 \pm 0.1118 \mathrm{a}$ & $0.5713 \pm 0.1201 \mathrm{a}$ \\
\hline & Basidiomycota & $0.2583 \pm 0.0571 \mathrm{a}$ & $0.3034 \pm 0.0485 \mathrm{a}$ & $0.25 \pm 0.0951 \mathrm{a}$ & $0.3282 \pm 0.1343 \mathrm{a}$ \\
\hline & Chytridiomycota & $0.0004 \pm 0.0002 \mathrm{a}$ & $0.0002 \pm 0 \mathrm{a}$ & $0.0001 \pm 0.0001 \mathrm{a}$ & $0.0003 \pm 0.0002 \mathrm{a}$ \\
\hline & Mortierellomycota & $0.1487 \pm 0.0459 \mathrm{a}$ & $0.0943 \pm 0.0343 \mathrm{ab}$ & $0.0309 \pm 0.0142 b$ & $0.0881 \pm 0.0105 \mathrm{ab}$ \\
\hline & Mucoromycota & $0.0001 \pm 0 \mathrm{~b}$ & $0 \pm 0 \mathrm{~b}$ & $0.0002 \pm 0.0001 \mathrm{~b}$ & $0.0106 \pm 0.008 \mathrm{a}$ \\
\hline & Rozellomycota & $0.0039 \pm 0.0012 \mathrm{ab}$ & $0.0067 \pm 0.001 \mathrm{a}$ & $0.0062 \pm 0.0033 \mathrm{a}$ & $0.0014 \pm 0.0009 \mathrm{~b}$ \\
\hline
\end{tabular}

Note: The data presented in the table are the percentage of the number of OTUs of bacteria and fungi to the total number of OTUs. The significance of post hoc pairwise comparisons was determined using Tukey's LSD test under a significance level of 0.05. Additionally, analyses were performed using the software package IBM SPSS statistics 20.0 for Windows. We repeated each treatment three times $(n=3)$; for each treatment, means in the same line with different lowercase letters differ significantly $(p<0.05)$. 
Table 3. Relative abundance of bacteria and fungi at the genus level in paddy soil with different levels of straw additions.

\begin{tabular}{|c|c|c|c|c|c|c|}
\hline Kingdom & Phylum & Genus & $\begin{array}{l}0 \% \text { Straw } \\
\text { Returning }\end{array}$ & $\begin{array}{l}50 \% \text { Straw } \\
\text { Returning }\end{array}$ & $\begin{array}{l}75 \% \text { Straw } \\
\text { Returning }\end{array}$ & $\begin{array}{l}100 \% \text { Straw } \\
\text { Returning }\end{array}$ \\
\hline \multirow{26}{*}{ Bacteria } & \multirow{3}{*}{ Actinobacteria } & Arthrobacter & $0.1182 \pm 0.0041 \mathrm{a}$ & $0.1641 \pm 0.0128 \mathrm{a}$ & $0.1729 \pm 0.0232 \mathrm{a}$ & $0.15 \pm 0.0435 \mathrm{a}$ \\
\hline & & Terracoccus & $0.0193 \pm 0.0006 \mathrm{a}$ & $0.0135 \pm 0.0013 b$ & $0.0159 \pm 0.0008 b$ & $0.0104 \pm 0.0021 \mathrm{c}$ \\
\hline & & Nocardioides & $0.042 \pm 0.0019 \mathrm{a}$ & $0.0403 \pm 0.004 \mathrm{ab}$ & $0.0354 \pm 0.0024 \mathrm{~b}$ & $0.0273 \pm 0.0016 \mathrm{c}$ \\
\hline & \multirow{3}{*}{ Acidobacteria } & Candidatussolibacter & $0.0436 \pm 0.0041 \mathrm{a}$ & $0.0337 \pm 0.0027 \mathrm{ab}$ & $0.0287 \pm 0.0068 \mathrm{~b}$ & $0.0254 \pm 0.0036 \mathrm{~b}$ \\
\hline & & Candidatuskoribacter & $0.0317 \pm 0.0019 \mathrm{~b}$ & $0.0381 \pm 0.0029 \mathrm{a}$ & $0.0256 \pm 0.0014 \mathrm{c}$ & $0.0206 \pm 0.0036 c$ \\
\hline & & Geothrix & $0.0058 \pm 0.0007 \mathrm{~b}$ & $0.0086 \pm 0.0015 b$ & $0.0129 \pm 0.0016 \mathrm{a}$ & $0.0093 \pm 0.0017 \mathrm{~b}$ \\
\hline & \multirow{2}{*}{ Bacteroidetes } & Flavobacterium & $0.0045 \pm 0.0022 \mathrm{~b}$ & $0.0245 \pm 0.0078 \mathrm{a}$ & $0.0202 \pm 0.0054 \mathrm{a}$ & $0.0262 \pm 0.0049 a$ \\
\hline & & Paludibacter & $0.0003 \pm 0.0002 \mathrm{c}$ & $0.0006 \pm 0.0003 c$ & $0.0136 \pm 0.0025 \mathrm{a}$ & $0.0049 \pm 0.0006 \mathrm{~b}$ \\
\hline & Chloroflexi & Anaerolinea & $0.0393 \pm 0.0147 \mathrm{a}$ & $0.0328 \pm 0.0066 \mathrm{a}$ & $0.0404 \pm 0.0144 \mathrm{a}$ & $0.0321 \pm 0.0124 \mathrm{a}$ \\
\hline & Cyanobacteria & Leptolyngbya & $0.0076 \pm 0.0012 b$ & $0.0172 \pm 0.005 \mathrm{a}$ & $0.0045 \pm 0.001 \mathrm{~b}$ & $0.006 \pm 0.0025 b$ \\
\hline & Firmicutes & Clostridium & $0.0058 \pm 0.001 \mathrm{~b}$ & $0.0074 \pm 0.001 \mathrm{~b}$ & $0.012 \pm 0.0024 \mathrm{a}$ & $0.0084 \pm 0.0015 \mathrm{ab}$ \\
\hline & Nitrospirae & Nitrospira & $0.0248 \pm 0.0047 \mathrm{a}$ & $0.0157 \pm 0.0044 \mathrm{~b}$ & $0.0127 \pm 0.0025 \mathrm{~b}$ & $0.0121 \pm 0.0029 \mathrm{~b}$ \\
\hline & \multirow{14}{*}{ Proteobacteria } & Geobacter & $0.0951 \pm 0.0083 \mathrm{~b}$ & $0.074 \pm 0.0126 \mathrm{~b}$ & $0.1459 \pm 0.0044 \mathrm{a}$ & $0.1461 \pm 0.0303 \mathrm{a}$ \\
\hline & & Crenothrix & $0.0044 \pm 0.0006 \mathrm{~b}$ & $0.0039 \pm 0.0003 \mathrm{~b}$ & $0.0089 \pm 0.0008 b$ & $0.0568 \pm 0.0076 \mathrm{a}$ \\
\hline & & Anaeromyxobacter & $0.0675 \pm 0.0055 \mathrm{a}$ & $0.0613 \pm 0.0073 \mathrm{a}$ & $0.0726 \pm 0.0063 a$ & $0.0595 \pm 0.006 \mathrm{a}$ \\
\hline & & Rhodoplanes & $0.0912 \pm 0.0016 \mathrm{a}$ & $0.0569 \pm 0.0081 \mathrm{~b}$ & $0.0428 \pm 0.0064 \mathrm{~b}$ & $0.0504 \pm 0.0081 \mathrm{~b}$ \\
\hline & & Pseudomonas & $0.0019 \pm 0.0007 \mathrm{~b}$ & $0.0087 \pm 0.0027 \mathrm{ab}$ & $0.0122 \pm 0.0033 \mathrm{ab}$ & $0.0228 \pm 0.012 \mathrm{a}$ \\
\hline & & Methylosinus & $0.0208 \pm 0.0025 \mathrm{~b}$ & $0.0358 \pm 0.005 \mathrm{a}$ & $0.0196 \pm 0.0034 \mathrm{~b}$ & $0.0279 \pm 0.0031 \mathrm{ab}$ \\
\hline & & Syntrophobacter & $0.0568 \pm 0.0014 \mathrm{a}$ & $0.053 \pm 0.0061 \mathrm{a}$ & $0.0317 \pm 0.0036 \mathrm{~b}$ & $0.0347 \pm 0.004 \mathrm{~b}$ \\
\hline & & Methylibium & $0.0189 \pm 0.0026 \mathrm{a}$ & $0.0167 \pm 0.0012 \mathrm{a}$ & $0.0094 \pm 0.0019 \mathrm{~b}$ & $0.0156 \pm 0.0011 \mathrm{a}$ \\
\hline & & Desulfobacca & $0.0265 \pm 0.0034 \mathrm{a}$ & $0.0219 \pm 0.0028 \mathrm{a}$ & $0.024 \pm 0.0037 \mathrm{a}$ & $0.014 \pm 0.0009 \mathrm{~b}$ \\
\hline & & Phenylobacterium & $0.0164 \pm 0.0032 \mathrm{~b}$ & $0.0257 \pm 0.0031 \mathrm{a}$ & $0.0078 \pm 0.0014 c$ & $0.0138 \pm 0.0017 \mathrm{~b}$ \\
\hline & & Variovorax & $0.0093 \pm 0.001 \mathrm{a}$ & $0.0116 \pm 0.0005 a$ & $0.0087 \pm 0.0033 \mathrm{a}$ & $0.0117 \pm 0.0006 \mathrm{a}$ \\
\hline & & Thiobacillus & $0.0338 \pm 0.0156 \mathrm{a}$ & $0.0135 \pm 0.0038 \mathrm{a}$ & $0.0166 \pm 0.0031 \mathrm{a}$ & $0.019 \pm 0.0061 \mathrm{a}$ \\
\hline & & Reyranella & $0.0139 \pm 0.0024 \mathrm{a}$ & $0.0096 \pm 0.0007 \mathrm{~b}$ & $0.0049 \pm 0.0009 c$ & $0.0085 \pm 0.0009 \mathrm{~b}$ \\
\hline & & Hyphomicrobium & $0.0115 \pm 0.0006 \mathrm{a}$ & $0.0103 \pm 0.0009 \mathrm{a}$ & $0.0076 \pm 0.0007 b$ & $0.0068 \pm 0.0006 \mathrm{~b}$ \\
\hline \multirow{20}{*}{ Fungi } & \multirow{14}{*}{ Ascomycota } & Pseudogymnoascus & $0.1055 \pm 0.0144 \mathrm{ab}$ & $0.1369 \pm 0.0467 \mathrm{ab}$ & $0.2349 \pm 0.1072 \mathrm{a}$ & $0.0276 \pm 0.0104 \mathrm{~b}$ \\
\hline & & Didymella & $0.1692 \pm 0.0623 \mathrm{a}$ & $0.055 \pm 0.0224 \mathrm{~b}$ & $0.0748 \pm 0.0394 \mathrm{~b}$ & $0.019 \pm 0.0053 \mathrm{~b}$ \\
\hline & & Echria & $0.0392 \pm 0.0074 \mathrm{~b}$ & $0.1942 \pm 0.0648 \mathrm{a}$ & $0.0353 \pm 0.0227 \mathrm{~b}$ & $0.0261 \pm 0.0202 b$ \\
\hline & & Setophoma & $0.0073 \pm 0.0044 \mathrm{~b}$ & $0.0068 \pm 0.0049 \mathrm{~b}$ & $0.205 \pm 0.163 \mathrm{a}$ & $0.0036 \pm 0.0008 \mathrm{~b}$ \\
\hline & & Fusicolla & $0.0001 \pm 0 \mathrm{~b}$ & $0 \pm 0 \mathrm{~b}$ & $0.0003 \pm 0.0003 \mathrm{~b}$ & $0.3394 \pm 0.2546 \mathrm{a}$ \\
\hline & & Candida & $0.0253 \pm 0.0061 \mathrm{a}$ & $0.0098 \pm 0.0018 b$ & $0.0122 \pm 0.003 \mathrm{~b}$ & $0.0125 \pm 0.0057 b$ \\
\hline & & Xenopolyscytalum & $0.0129 \pm 0.0063 \mathrm{a}$ & $0.0048 \pm 0.0017 \mathrm{~b}$ & $0.0013 \pm 0.0002 b$ & $0.0037 \pm 0.0022 \mathrm{~b}$ \\
\hline & & Articulospora & $0.0641 \pm 0.0382 \mathrm{a}$ & $0.0002 \pm 0.0001 \mathrm{~b}$ & $0.0002 \pm 0.0001 \mathrm{~b}$ & $0.016 \pm 0.0102 \mathrm{~b}$ \\
\hline & & Pyrenochaetopsis & $0.0369 \pm 0.0186 \mathrm{a}$ & $0.0268 \pm 0.0132 \mathrm{a}$ & $0.0126 \pm 0.0015 a$ & $0.0218 \pm 0.0066 \mathrm{a}$ \\
\hline & & Cladosporium & $0.0232 \pm 0.0064 \mathrm{a}$ & $0.0142 \pm 0.007 \mathrm{a}$ & $0.0449 \pm 0.0364 \mathrm{a}$ & $0.0168 \pm 0.0051 \mathrm{a}$ \\
\hline & & Microdochium & $0.0139 \pm 0.004 \mathrm{a}$ & $0.0035 \pm 0.0013 \mathrm{~b}$ & $0.0041 \pm 0.0022 \mathrm{~b}$ & $0.0037 \pm 0.0016 \mathrm{~b}$ \\
\hline & & Nigrospora & $0.0177 \pm 0.0071 \mathrm{a}$ & $0.0069 \pm 0.002 \mathrm{~b}$ & $0.0027 \pm 0.0007 \mathrm{~b}$ & $0.0079 \pm 0.005 \mathrm{ab}$ \\
\hline & & Aspergillus & $0.0064 \pm 0.0026 \mathrm{a}$ & $0.0022 \pm 0.0006 \mathrm{a}$ & $0.0047 \pm 0.0021 \mathrm{a}$ & $0.0028 \pm 0.001 \mathrm{a}$ \\
\hline & & Talaromyces & $0.0033 \pm 0.0017 \mathrm{a}$ & $0.0012 \pm 0.0002 \mathrm{~b}$ & $0.001 \pm 0.0003 \mathrm{~b}$ & $0.0007 \pm 0.0003 \mathrm{~b}$ \\
\hline & \multirow{5}{*}{ Basidiomycota } & Papiliotrema & $0.0079 \pm 0.003 \mathrm{~b}$ & $0.0072 \pm 0.0022 \mathrm{~b}$ & $0.0122 \pm 0.0037 \mathrm{ab}$ & $0.0225 \pm 0.0088 \mathrm{a}$ \\
\hline & & Guehomyces & $0.1033 \pm 0.0324 \mathrm{a}$ & $0.0894 \pm 0.0164 \mathrm{a}$ & $0.08 \pm 0.0305 a$ & $0.1095 \pm 0.0667 \mathrm{a}$ \\
\hline & & Solicoccozyma & $0.0559 \pm 0.0183 \mathrm{a}$ & $0.042 \pm 0.0013 \mathrm{a}$ & $0.0661 \pm 0.0246 \mathrm{a}$ & $0.1009 \pm 0.0566 \mathrm{a}$ \\
\hline & & Psilocybe & $0.0423 \pm 0.0153 \mathrm{a}$ & $0.1351 \pm 0.0966 \mathrm{a}$ & $0.017 \pm 0.0063 \mathrm{a}$ & $0.0258 \pm 0.014 \mathrm{a}$ \\
\hline & & Mrakia & $0.0283 \pm 0.0065 \mathrm{a}$ & $0.0294 \pm 0.0034 \mathrm{a}$ & $0.0713 \pm 0.0351 \mathrm{a}$ & $0.0619 \pm 0.0257 \mathrm{a}$ \\
\hline & Mortierellomycota & Mortierella & $0.16 \pm 0.05 a$ & $0.102 \pm 0.0345 \mathrm{ab}$ & $0.0312 \pm 0.0135 \mathrm{~b}$ & $0.0681 \pm 0.0135 \mathrm{~b}$ \\
\hline
\end{tabular}

Note: The data presented in the table are the percentage of the number of OTUs of bacteria and fungi to the total number of OTUs. The significance of post hoc pairwise comparisons was determined using Tukey's LSD test under a significance level of 0.05. Additionally, analyses were performed using the software package IBM SPSS statistics 20.0 for Windows. We repeated each treatment three times $(n=3)$; for each treatment, means in the same line with different lowercase letters differ significantly $(p<0.05)$.

\subsubsection{Compositional Characteristics of Soil Fungal Communities under Different Straw Addition Levels}

The relative abundances of the fungal phyla at different levels of straw addition were shown in Figure 2B. The main fungal phyla were Ascomycota (20.92-85.20\%), Basidiomycota (13.02-50.51\%), and Mortierellomycota (15.88-20.42\%). We found that the amount of straw added had no significant effect on the fungal phylum level. Only Mucoromycota became more abundant when high levels of straw were added (Table 2). Further analysis of the level of fungi with a relative abundance of more than $1 \%$ (Table 3) showed that the 
addition of straw had a particular effect on the fungi genus level. The addition of straw reduced the relative abundance of several genera of putative pathogens (Didymella, Candida, Articulospora, Microdochium, Nigrospora, Talaromyces, and Mortierella).

\subsection{Correlation between Bacteria and Fungi under Different Straw Addition Levels}

Co-inertial analysis (COIA) was used to investigate the covariance of the bacterial and fungal community structure in paddy soil under different straw additions (Figure 3). The plotting results of the bacterial and fungal communities were combined into a new ordination plot, in which the positions of the bacterial and fungal communities were linked using arrows. We observed that the variation between the bacterial and fungal communities significantly differed between treatments involving different straw additions $(p=0.001)$. When different amounts of straw were added, the synergistic correlation between bacterial communities and fungal communities in paddy soil showed different changes (the arrow directions indicated by the four treatments are not consistent). Among them, the arrow of the medium-level straw addition treatment was shorter than those of other treatments, indicating that the correlation between the bacterial and fungal communities in the paddy soil under a medium level of straw addition was the strongest among the four treatments. On the contrary, the correlation between the bacterial and fungal communities in the paddy soil with $100 \%$ straw returning was the weakest among the four treatments.

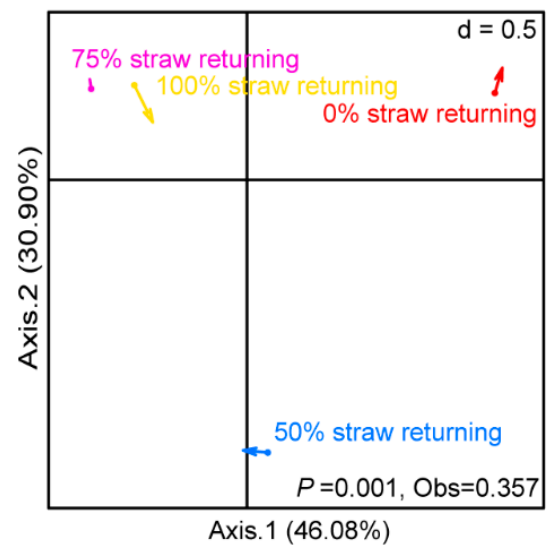

Figure 3. Co-inertia analysis (CIA) of bacteria and fungi when different amounts of straw were added. The direction of the arrow indicates the trend of the correlation between bacteria and fungi, while the length of the arrow indicates the strength of the correlation between bacteria and fungi. Each group had three replicates $(n=3)$. After Monte Carlo test, $p=0.001$.

\subsection{The Network Correlation between Bacteria and Fungi under Different Amounts of Straw Returning}

In this study, we used network analysis (based on $|R|=0.8, p<0.01$ ) to explore the impact of returning different amounts of straw to paddy soil on the ecological correlation between bacteria and fungi (Figure 4). Multiple network topology indicators consistently showed that the networks of fields that had different amounts of straw added were obviously different. As shown in Figure 4, the number of edges of the co-occurrence network of the bacterial and fungal communities at the phylum level was affected by the amount of straw returned (Figure $4 \mathrm{E}, \mathrm{F}$ ). The network of the medium-level straw addition displayed the highest edge numbers among the four treatments, while the network treatment with only low-level straw addition displayed the most negligible edge numbers. With the exception of the low-level straw addition treatment, the bacterial and fungal communities of the other three treatment groups were more positively correlated (Figure 4E). The proportion of positive correlation out of the total correlation was specifically expressed as high-level straw addition $(56.99 \%)>$ medium-level straw addition $(51.18 \%)>$ no straw addition $(50.53 \%)>$ low-level straw addition $(43.37 \%)$. For the average degree (Figure $4 \mathrm{G}$ ) and 
connectance (Figure $4 \mathrm{H}$ ) of the network, the fungal community and bacterial community were more complex in fields treated with a medium-level straw addition than in fields of other treatments.

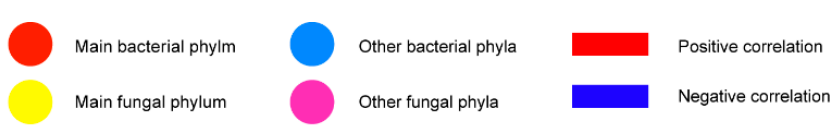

(A) $0 \%$ Straw returning

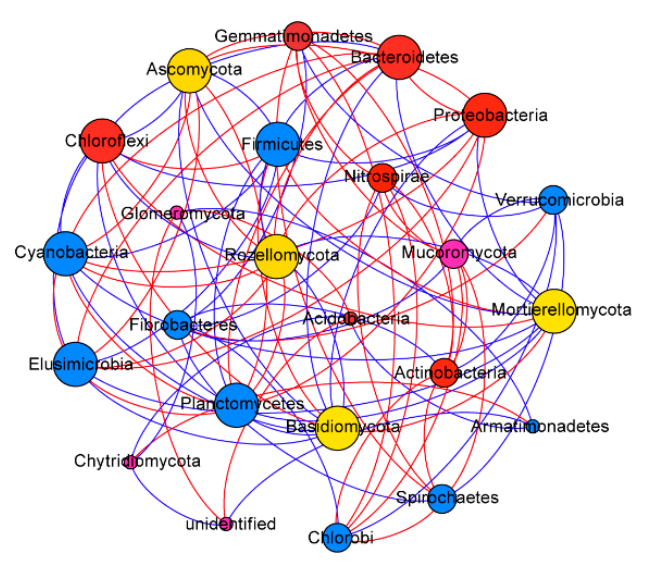

(C) $75 \%$ Straw returning
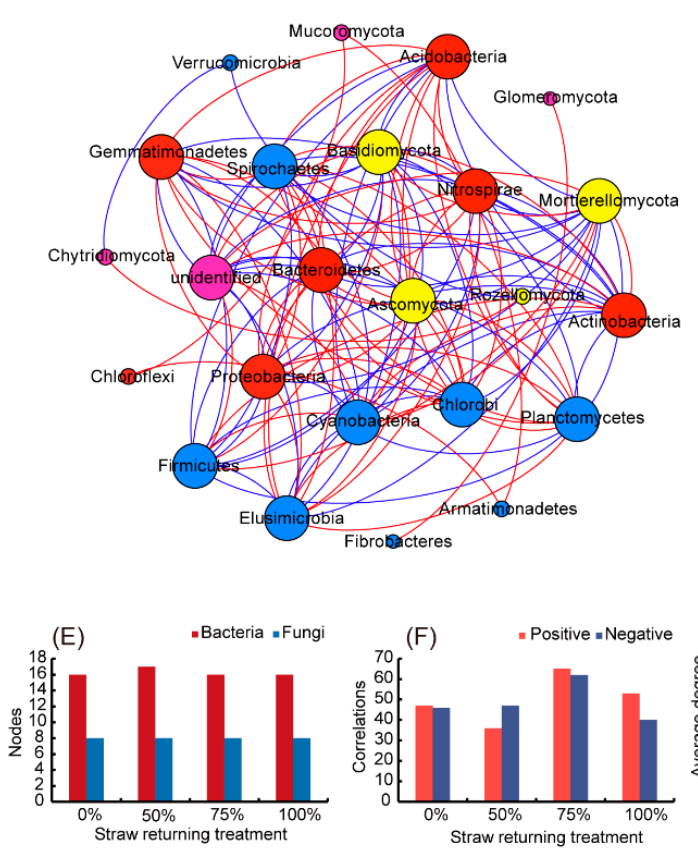

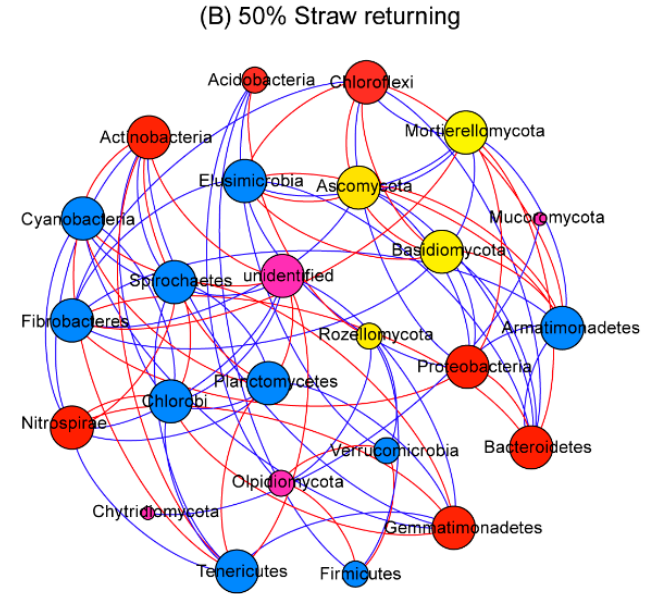

(D) $100 \%$ Straw returning
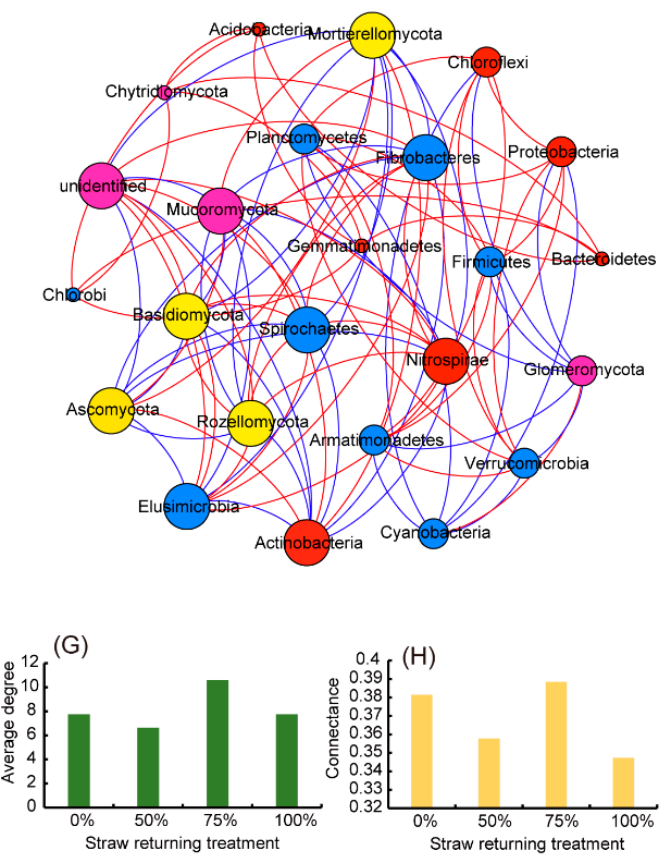

Figure 4. Network analysis between bacterial and fungal communities in fields treated with different amounts of straw. (A) network correlation between bacteria and fungi in no straw addition; (B) network correlation between bacteria and fungi in 50\% straw addition; (C) network correlation between bacteria and fungi in 75\% straw addition; (D) network correlation between bacteria and fungi in 100\% straw addition; (E) Number of nodes; (F) number of edges; (G) network average degree; (H) network complexity. The red and blue nodes represent the bacterial phyla, and the red nodes are the main bacterial phyla; the yellow and pink nodes are the fungal phyla, and the yellow nodes represent the main fungal phyla. The red lines indicate a positive correlation, and the blue lines indicate a negative correlation.

The size of each node is proportional to its correlations with other nodes. The bigger the size, the stronger and more significant were the correlations exhibited by the nodes [40]. 
We found that the effect of straw addition on the bacterial community was significantly higher than that on the fungal community. Figure 4 showed that the specific bacterial phyla had strong or weak correlations with other taxa under different amounts of straw additions. However, except for Rozellomycota, which had weak correlations with other groups in treatments with low and medium straw additions, the other major fungal phyla strongly correlated with other groups. In addition, Proteobacteria, Chloroflexi, and Bacteroidetes had a strong correlation with other taxa without straw additions (Figure 4A). Acidobacteria in low-level straw addition treatments and Chloroflexi in medium-level straw addition treatments had weak correlations with other taxa (Figure 4B,C), while Actinobacteria and Nitrospirae had strong correlations with other taxa in treatments with a high level of straw addition (Figure 4D).

\section{Discussion}

Rice cultivation has produced a large amount of rice straw. In order to promote the development of green agriculture, the practice of returning straw to fields has become more and more common in northeast China [9-11]. Previous studies have shown that returning straw to the field has significant effects on the physical and chemical properties of the soil and the microbial community [41-43]. However, research on the effect of the quantity of straw returned to the field on the soil microbial community is relatively scarce. In this study, we evaluated the effects of different amounts of straw additions on the microbial community in paddy soil and explored the relationship between the bacterial and fungal communities.

In this study, we kept the soil free from special factors as much as possible and ensured that the amount of straw added was the main factor affecting the soil microbial community. The results showed that the amount of straw added did not affect the diversity of the bacterial community, but did change the abundance of the fungal community (Table 1). The composition of the bacterial community is more susceptible to low levels of straw additions, while the composition of the fungal community is more susceptible to high levels of straw additions (Figure 1). Generally speaking, bacteria prefer to decompose unstable organic compounds and occupy a dominant position in the early stage of straw decomposition $[44,45]$, while fungi prefer to decompose difficult-to-degrade organic compounds and occupy a dominant position in the later stage of straw decomposition [46]. Therefore, when the amount of returned straw is high, the amount of unstable organic matter will greatly increase, and more substrate will make the bacterial community multiply faster than the fungal community at the early stage of straw decomposition [47]. Due to the lack of oxygen in rice fields, the bacterial community consumes most of the oxygen in the early stage of straw decomposition, resulting in the inability of the fungal community to survive (most fungi are aerobic microorganisms) [48,49]. In addition, the fungal community is seemingly less competitive than the bacterial community under the cold climate in northeast China [50]. Therefore, the abundance and composition of the soil fungal community are significantly affected by the straw additions. It is worth noting that we found that there is a discrete point in the $100 \%$ straw return treatment group that is far away from the other discrete points (Figure 1B). This may be due to the uneven return of the straw to the paddy soil during the experiment, which caused this discrete point to be similar to the clustering of the $75 \%$ straw returning treatment group.

The composition of the microbial community is an important basis of microbial functions [51]. We found that the amount of straw added changed the composition of the microbial community (Figure 2). Specifically, the addition of straw has little effect on the relative abundance of fungal taxa, but significantly affects the relative abundances of some bacterial taxa (Bacteroidetes, Acidobacteria, Cyanobacteria, Nitrosoirae, Proteobacteria, and Gemmatimonadetes). In addition, adding different amounts of straw also has different enrichment effects. The relative abundance of Acidobacteria was higher in fields treated with low-level straw additions ( $50 \%$ straw returning) than that of fields treated with large amounts of straw additions ( $>50 \%$ straw returning). Studies have shown that the main 
function of Acidobacteria is to degrade the polymers of plant residues, and the abundance of Acidobacteria will increase in low organic carbon content soils [52]. This may suggest that adding a small amount of straw will increase the acidic environment and low organic carbon content in the paddy soil, which leads to the increase of Acidobacteria. One study reported organic carbon content in the paddy soil was increased with the amount of straw returned, while the abundances of Acidobacteria and Nitrospira decreased [53]. Nitrospira is the main microorganism in the nitrosation reaction that oxidizes nitrite to nitrate [54]. However, Nitrospira does not adapt to acidic environments caused by the straw addition, affecting the nitrogen cycle in paddy soil [54].

With the addition of a large amount of straw ( $>50 \%$ straw returning), the relative abundances of Proteobacteria and Bacteroidetes increased significantly (Table 2). Proteobacteria is the most important bacterial group in paddy soil and actively participates in the process of soil denitrification [55,56]. The relative abundances of Geobacter and Crenohrix in Proteobacteria increased significantly at high levels of straw addition (Table 3), which may contribute to the iron cycle process in paddy soil [57]. The relative abundances of Syntrophobacter and Desulfobacca in Proteobacteria decreased (Table 3), indicating that, with the addition of straw, the process of sulfur reduction in rice fields may be inhibited to a certain extent [58,59]. Bacteroidetes are often used to evaluate soil utilization [60], and Flavobacterium in Bacteroidetes is a decomposer of refractory fibers, such as lignin in straw [61]. The increase in Bacteroidetes and Proteobacteria has a positive effect on the soil carbon cycle [60,62]. Both Gemmatimonadetes and Pseudomonas contain a variety of taxa that inhibit pathogenic microorganisms [63,64]. The relative abundance of Gemmatimonadetes decreased significantly after adding straw, while the relative abundance of Pseudomonas increased significantly when straw was returned to the field at a high level. At the same time, several genera of putative pathogens (Didymella, Candida, Xenophyllcytalum, Articulospora, Microdochium, Nigrospora, and Talaromyces) also decreased [65,66]. The reason may be that flooded environments are not suitable for the growth of Gemmatimonadetes, making Pseudomonas the leading group that inhibits pathogens in rice fields.

Network analysis provides a way to investigate microbial communities by revealing non-random covariant patterns in community organizations [67]. Analyzing the structural characteristics of the ecological network may detect complex relationships between species and the stability of the ecological network structure $[68,69]$. The complexity of the network is indicated by the number and density of its nodes and edges [70]. In this study, the different returning amounts of straw resulted in completely different correlations between bacteria and fungi (Figure 3). Through network analysis (Figure 4), we found that the amount of straw added was the main factor driving the correlation among microorganisms in the paddy soil. The network correlation of microbial communities was more complicated at a medium level of straw returning, while the network correlation of bacteria and fungi communities was less complicated in other treatments of straw returning. Large straw additions ( $>50 \%$ straw addition) made the positive correlation between bacteria and fungus communities stronger. On the contrary, the addition of a small amount of straw $(\leq 50 \%$ straw addition) not only reduced the complexity of the network but also reduced the positive correlation between bacterial and fungal communities (reduced the number of edges, average degree, and complexity of the network). Given that associations in co-occurrence networks may imply ecological interactions or niche sharing between microorganisms [71], adding a large amount of straw ( $>50 \%$ straw addition) may foster interactions or encourage more microbes to share niches, thereby comprehensively improving the ecological environment of paddy soil.

\section{Conclusions}

In conclusion, returning straw to the field triggered changes in the abundance and composition of the microbial community in paddy soil. With an increase in the amount of straw returned, the abundance of the fungal community decreased significantly. When the amount of straw added was low ( $\leq 50 \%$ straw added), the composition of the bacterial 
community was more susceptible, while when the amount of straw added was high $(>50 \%$ straw added), the fungal community was more likely to be affected. The addition of a low-level straw addition increased the relative abundance of acidic microorganisms in paddy soil and reduced the relative abundance of nitrifying microorganisms, which was not conducive to the nitrogen cycle process in paddy soil. Straw returning at a medium or high level increased the abundance of the microbiomes related to carbon and iron metabolism, which may help the carbon and iron cycle in paddy soil. In addition, adding a large amount of straw ( $>50 \%$ straw addition) increased the complexity of the microbial network and may promote more niche-sharing, thereby comprehensively improving the ecological environment of the paddy soil. This study only describes the changes in the microbial community in the paddy soil after two years of rice straw being returned to the field, and further research is needed on the effect of the long-term addition of returning different amounts of straw on the paddy soil microbial community.

Author Contributions: C.T. and F.J. designed the experiments. E.W. and X.L. performed the experiments, collected the samples, extracted the DNA and wrote the manuscript. L.T., X.W. and L.J. analyzed the raw sequencing data. All authors have read and agreed to the published version of the manuscript.

Funding: This work is financially supported by the Special Foundation for Basic Research Program in Wild China of CAS (XDA23070500), National Natural Science Foundation of China (42007043, 51279197, 31370144, 41571255), the Special Foundation for State Major Basic Research Program of China (2016YFC0501202), Special Foundation for Basic Research Program in Soil of CAS (XDB15030103), Key Laboratory Foundation of Mollisols Agroecology (2016ZKHT-05), 135 Project of Northeast Institute of Geography and Agroecology (Y6H2043001), and Jilin Province Natural Science Foundation (20140101017JC).

Data Availability Statement: All raw and processed data are available on NCBI under the bioproject number PRJNA639877.

Acknowledgments: We would like to thank the staffs in Shanghai Personal Biotechnology Co., Ltd. for advice on the data analysis.

Conflicts of Interest: The authors declare no conflict of interest.

\section{Appendix A}
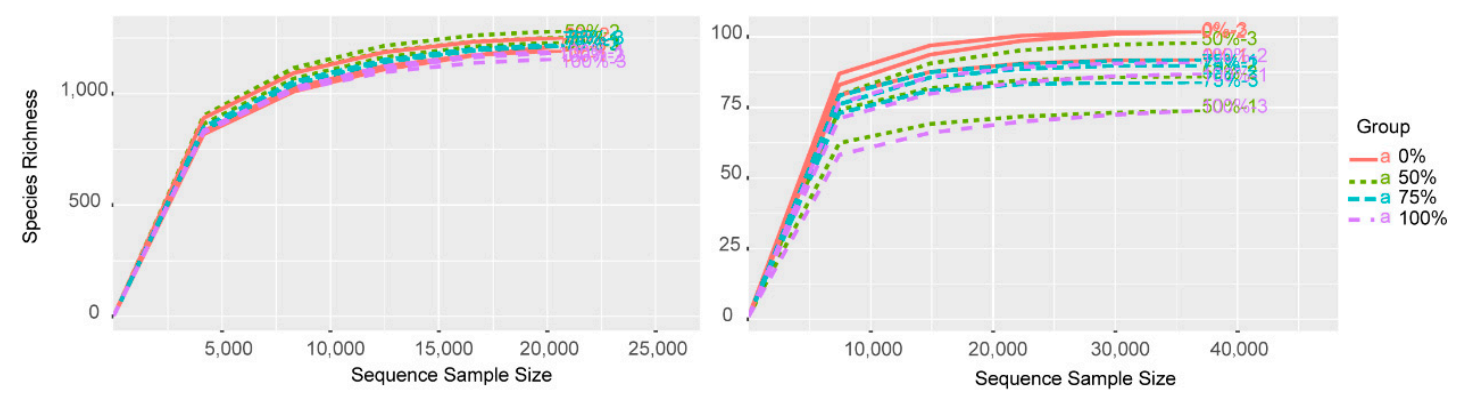

Figure A1. OTU rarefaction curve for bacterial and fungal communities with different amounts of straw added. Each group had three replicates $(n=3)$. The left picture shows bacterial OTUs and the right picture shows fungal OTUs. 
Table A1. Network parameters in the network relationship between bacterial and fungal communities at the phylum level with different amounts of straw added. Each group had three replicates $(n=3)$.

\begin{tabular}{ccccc}
\hline $\begin{array}{c}\text { Network Parameter } \\
\text { Characteristics }\end{array}$ & $\mathbf{0 \%}$ Straw Returning & $\mathbf{5 0} \%$ Straw Returning & $\mathbf{7 5 \%}$ Straw Returning & $\mathbf{1 0 0 \%}$ Straw Returning \\
\hline Bacteria notes & 16 & 17 & 16 & 16 \\
Fungi notes & 8 & 8 & 8 & 8 \\
Positive correlations & 47 & 36 & 65 & 53 \\
Negative correlations & 46 & 47 & 62 & 70 \\
Average degree & 7.75 & 6.64 & 0.46 & 0.337 \\
Density & 0.337 & 0.277 & 0.106 & 0.548 \\
Modularity & 0.548 & 0.609 & 0.3885 & 0.3473 \\
Connectance & 0.3815 & 0.3578 & & \\
\hline
\end{tabular}

\section{References}

1. Liu, X.B.; Zhang, X.Y.; Wang, Y.X.; Sui, Y.Y.; Zhang, S.L.; Herbert, S.J. Soil degradation: A problem threatening the sustainable development of agriculture in Northeast China. Plant Soil Environ. 2010, 56, 87-97. [CrossRef]

2. Liu, J.J.; Sui, Y.Y.; Yu, Z.H.; Shi, Y.; Chu, H.Y.; Jin, J. Soil carbon content drives the biogeographical distribution of fungal communities in the black soil zone of northeast China. Soil Biol. Biochem. 2015, 83, 29-39. [CrossRef]

3. von Luetzow, M.; Koegel-Knabner, I.; Ekschmitt, K.; Matzner, E.; Guggenberger, G. Stabilization of organic matter in temperate soils: Mechanisms and their relevance under different soil conditions-A review. Eur. J. Soil Sci. 2006, 57, 426-445. [CrossRef]

4. Zhang, P.; Wei, T.; Jia, Z.K.; Han, Q.F.; Ren, X.L. Soil aggregate and crop yield changes with different rates of straw incorporation in semiarid areas of northwest China. Geoderma 2014, 230, 41-49. [CrossRef]

5. Kuzyakov, Y.; Friedel, J.K.; Stahr, K. Review of mechanisms and quantification of priming effects. Soil Biol. Biochem. 2000, 32, 1485-1498. [CrossRef]

6. Song, C.; Wang, E.L.; Han, X.Z.; Stirzaker, R. Crop production, soil carbon and nutrient balances as affected by fertilisation in a Mollisol agroecosystem. Nutr. Cycl. Agroecosys 2011, 89, 363-374. [CrossRef]

7. Shahbaz, M.; Kumar, A.; Kuzyakov, Y.; Borjesson, G.; Blagodatskaya, E. Priming effects induced by glucose and decaying plant residues on SOM decomposition: A three-source C-13/C-14 partitioning study. Soil Biol. Biochem. 2018, 121, 138-146. [CrossRef]

8. Li, H.; Cao, Y.; Wang, X.M.; Ge, X.; Li, B.Q.; Jin, C.Q. Evaluation on the Production of Food Crop Straw in China from 2006 to 2014. BioEnergy Res. 2017, 10, 949-957. [CrossRef]

9. Yang, H.S.; Fang, C.; Meng, Y.; Dai, Y.J.; Liu, J. Long-term ditch-buried straw return increases functionality of soil microbial communities. Catena 2021, 202, 105316. [CrossRef]

10. Shan, J.; Yan, X.Y. Effects of crop residue returning on nitrous oxide emissions in agricultural soils. Atmos. Environ. 2013, 71, 170-175. [CrossRef]

11. Karami, A.; Homaee, M.; Afzalinia, S.; Ruhipour, H.; Basirat, S. Organic resource management: Impacts on soil aggregate stability and other soil physico-chemical properties. Agric. Ecosyst. Environ. 2012, 148, 22-28. [CrossRef]

12. Blagodatskaya, E.V.; Blagodatsky, S.A.; Anderson, T.H.; Kuzyakov, Y. Priming effects in Chernozem induced by glucose and N in relation to microbial growth strategies. Appl. Soil Ecol. 2007, 37, 95-105. [CrossRef]

13. Henriksen, T.M.; Breland, T.A. Carbon mineralization, fungal and bacterial growth, and enzyme activities as affected by contact between crop residues and soil. Biol. Fertil. Soils 2002, 35, 41-48. [CrossRef]

14. Geisseler, D.; Horwath, W.R.; Scow, K.M. Soil moisture and plant residue addition interact in their effect on extracellular enzyme activity. Pedobiologia 2011, 54, 71-78. [CrossRef]

15. Zhao, S.C.; Qiu, S.J.; Xu, X.P.; Ciampitti, I.A.; Zhang, S.Q.; He, P. Change in straw decomposition rate and soil microbial community composition after straw addition in different long-term fertilization soils. Appl. Soil Ecol. 2019, 138, 123-133. [CrossRef]

16. Kamble, P.N.; Baath, E. Comparison of fungal and bacterial growth after alleviating induced N-limitation in soil. Soil Biol. Biochem. 2016, 103, 97-105. [CrossRef]

17. Chibuike, G.; Burkitt, L.; Bretherton, M.; Singh, R.; Bishop, P. Dissolved Organic Carbon Concentration and Denitrification Capacity of a New Zealand Hill Country Soil After Forage Crop Establishment. Earth Syst. Environ. 2021, 1-14. [CrossRef]

18. Zhao, D.S.; Zheng, D.; Wu, S.H.; Wu, Z.F. Climate changes in northeastern China during last four decades. Chinese Geogr. Sci. 2007, 17, 317-324. [CrossRef]

19. Sun, W.M.; Xiao, E.Z.; Pu, Z.L.; Krumins, V.; Dong, Y.R.; Li, B.Q. Paddy soil microbial communities driven by environment- and microbe-microbe interactions: A case study of elevation-resolved microbial communities in a rice terrace. Sci. Total Environ. 2018, 612, 884-893. [CrossRef] [PubMed]

20. Wu, M.; Qin, H.L.; Chen, Z.; Wu, J.S.; Wei, W.X. Effect of long-term fertilization on bacterial composition in rice paddy soil. Biol. Fertil. Soils 2011, 47, 397-405. [CrossRef]

21. Kikuchi, H.; Watanabe, T.; Jia, Z.; Kimura, M.; Asakawa, S. Molecular analyses reveal stability of bacterial communities in bulk soil of a Japanese paddy field: Estimation by denaturing gradient gel electrophoresis of 16S rRNA genes amplified from DNA accompanied with RNA. Soil Sci. Plant Nutr. 2007, 53, 448-458. [CrossRef] 
22. Xia, Y.H.; Chen, X.B.; Zheng, X.D.; Deng, S.H.; Hu, Y.J.; Zheng, S.M. Preferential uptake of hydrophilic and hy-drophobic compounds by bacteria and fungi in upland and paddy soils. Soil Biol. Biochem. 2020, 148, 107879. [CrossRef]

23. Wei, L.; Ge, T.; Zhu, Z.; Luo, Y.; Yang, Y.; Xiao, M. Comparing carbon and nitrogen stocks in paddy and upland soils: Accumulation, stabilization mechanisms, and environmental drivers. Geoderma 2021, 398, 115121. [CrossRef]

24. Li, Y.H.; Shahbaz, M.; Zhu, Z.K.; Deng, Y.W.; Tong, Y.Y.; Chen, L. Oxygen availability determines key regulators in soil organic carbon mineralisation in paddy soils. Soil Biol. Biochem. 2021, 153, 108106. [CrossRef]

25. Chen, Z.; Luo, X.Q.; Hu, R.G.; Wu, M.N.; Wu, J.S.; Wei, W.X. Impact of Long-Term Fertilization on the Composition of Denitrifier Communities Based on Nitrite Reductase Analyses in a Paddy Soil. Microb. Ecol. 2010, 60, 850-861. [CrossRef]

26. Yang, H.S.; Feng, J.X.; Zhai, S.L.; Dai, Y.J.; Xu, M.M.; Wu, J.S. Long-term ditch-buried straw return alters soil water potential, temperature, and microbial communities in a rice-wheat rotation system. Soil Tillage Res. 2016, 163, 21-31. [CrossRef]

27. Zhao, S.C.; Li, K.J.; Zhou, W.; Qiu, S.J.; Huang, S.W.; He, P. Changes in soil microbial community, enzyme activities and organic matter fractions under long-term straw return in north-central China. Agric. Ecosyst. Environ. 2016, 216, 82-88. [CrossRef]

28. Klindworth, A.; Pruesse, E.; Schweer, T.; Peplies, J.; Quast, C.; Horn, M. Evaluation of general 16S ribosomal RNA gene PCR primers for classical and next-generation sequencing-based diversity studies. Nucleic Acids Res. 2013, 41, e1. [CrossRef]

29. Adams, R.I.; Miletto, M.; Taylor, J.W.; Bruns, T.D. Dispersal in microbes: Fungi in indoor air are dominated by outdoor air and show dispersal limitation at short distances. ISME J. 2013, 7, 1262-1273. [CrossRef]

30. Gardes, M.; Bruns, T.D. Its Primers with enhanced specificity for basidiomycetes-application to the identification of mycorrhizae and rusts. Mol. Ecol. 1993, 2, 113-118. [CrossRef]

31. White, T.J.; Bruns, T.; Lee, S.; Taylor, J. Amplification and direct sequencing of fungal ribosomal RNA genes for phylogenetics. In PCR Protocols: A Guide to Methods and Applications; Innis, M.A., Gelfand, D.H., Sninsky, J.J., White, T.J., Eds.; Academic Press Inc.: New York, NY, USA, 1990; pp. 315-322.

32. Caporaso, J.G.; Kuczynski, J.; Stombaugh, J.; Bittinger, K.; Bushman, F.D.; Costello, E.K. QIIME allows analysis of high-throughput community sequencing data. Nat. Methods 2010, 7, 335-336. [CrossRef] [PubMed]

33. Edgar, R.C. Search and clustering orders of magnitude faster than BLAST. Bioinformatics 2010, 26, 2460-2461. [CrossRef] [PubMed]

34. Feeley, K.J.; Davies, S.J.; Perez, R.; Hubbell, S.P.; Foster, R.B. Directional changes in the species composition of a tropical forest. Ecology 2011, 92, 871-882. [CrossRef]

35. Buttigieg, P.L.; Ramette, A. A guide to statistical analysis in microbial ecology: A community-focused, living review of multivariate data analyses. FEMS Microbiol. Ecol. 2014, 90, 543-550. [CrossRef] [PubMed]

36. Shi, S.H.; Tian, L.; Ma, L.N.; Tian, C.J. Community Structure of Rhizomicrobiomes in Four Medicinal Herbs and Its Im-plication on Growth Management. Microbiology 2018, 87, 425-436. [CrossRef]

37. Oksanen, J. Multivariate Analysis of Ecological Communities in R: Vegan Tutorial. 2011. Available online: https://www. yumpu.com/en/document/view/41285419/multivariate-analysis-of-ecological-communities-in-r-vegan-tutorial (accessed on 18 June 2021).

38. Yang, Y.Y.; Wang, W.B. Benzyldimethyldodecyl ammonium chloride shifts the proliferation of functional genes and microbial community in natural water from eutrophic lake. Environ. Pollut. 2018, 236, 355-365. [CrossRef] [PubMed]

39. Revelle, W.; Revelle, M.W. Package 'Psych'. The Comprehensive R Archive Network. 2015. Available online: http:/ / www.test. personality-project.org/r/psych/psych-manual.pdf (accessed on 20 January 2021).

40. Sun, W.M.; Xiao, E.Z.; Xiao, T.F.; Krumins, V.; Wang, Q.; Haggblom, M. Response of Soil Microbial Communities to Elevated Antimony and Arsenic Contamination Indicates the Relationship between the Innate Microbiota and Contaminant Fractions. Environ. Sci. Technol. 2017, 51, 9165-9175. [CrossRef] [PubMed]

41. Wu, L.P.; Ma, H.; Zhao, Q.L.; Zhang, S.R.; Wei, W.L.; Ding, X.D. Changes in soil bacterial community and enzyme activity under five years straw returning in paddy soil. Eur. J. Soil Biol. 2020, 100, 103215. [CrossRef]

42. Yan, S.S.; Song, J.M.; Fan, J.S.; Yan, C.; Dong, S.K.; Ma, C.M. Changes in soil organic carbon fractions and microbial community under rice straw return in Northeast China. Glob. Ecol. Conserv. 2020, 22, e00962. [CrossRef]

43. Bu, R.Y.; Ren, T.; Lei, M.J.; Liu, B.; Li, X.K.; Cong, R.H. Tillage and straw-returning practices effect on soil dissolved organic matter, aggregate fraction and bacteria community under rice-rice-rapeseed rotation system. Agric. Ecosyst. Environ. 2020, 287, 106681. [CrossRef]

44. Stemmer, M.; Watzinger, A.; Blochberger, K.; Haberhauer, G.; Gerzabek, M.H. Linking dynamics of soil microbial phospholipid fatty acids to carbon mineralization in a C-13 natural abundance experiment: Impact of heavy metals and acid rain. Soil Biol. Biochem. 2007, 39, 3177-3186. [CrossRef]

45. Paterson, E.; Sim, A.; Osborne, S.M.; Murray, P.J. Long-term exclusion of plant-inputs to soil reduces the functional capacity of microbial communities to mineralise recalcitrant root-derived carbon sources. Soil Biol. Biochem. 2011, 43, 1873-1880. [CrossRef]

46. Marschner, P.; Umar, S.; Baumann, K. The microbial community composition changes rapidly in the early stages of decomposition of wheat residue. Soil Biol. Biochem. 2011, 43, 445-451. [CrossRef]

47. Pastorelli, R.; Vignozzi, N.; Landi, S.; Piccolo, R.; Orsini, R.; Seddaiu, G. Consequences on macroporosity and bacterial diversity of adopting a no-tillage farming system in a clayish soil of Central Italy. Soil Biol. Biochem. 2013, 66, 78-93. [CrossRef]

48. Song, X.Y.; Spaccini, R.; Pan, G.; Piccolo, A. Stabilization by hydrophobic protection as a molecular mechanism for organic carbon sequestration in maize-amended rice paddy soils. Sci. Total Environ. 2013, 458-460, 319-330. [CrossRef] [PubMed] 
49. Qiu, H.S.; Ge, T.D.; Liu, J.Y.; Chen, X.B.; Hu, Y.J.; Wu, J.S. Effects of biotic and abiotic factors on soil organic matter mineralization: Experiments and structural modeling analysis. Eur. J. Soil Biol. 2018, 84, 27-34. [CrossRef]

50. de Boer, W.; Folman, L.B.; Summerbell, R.C.; Boddy, L. Living in a fungal world: Impact of fungi on soil bacterial niche development. FEMS Microbiol. Rev. 2005, 29, 795-811. [CrossRef]

51. Torsvik, V.; Ovreas, L.; Thingstad, T.F. Prokaryotic diversity-Magnitude, dynamics, and controlling factors. Science 2002, 296, 1064-1066. [CrossRef]

52. Liu, J.J.; Sui, Y.Y.; Yu, Z.H.; Yao, Q.; Shi, Y.; Chu, H.Y. Diversity and distribution patterns of acidobacterial communities in the black soil zone of northeast China. Soil Biol. Biochem. 2016, 95, 212-222. [CrossRef]

53. Shahbaz, M.; Kuzyakov, Y.; Sanaullah, M.; Heitkamp, F.; Zelenev, V.; Kumar, A. Microbial decomposition of soil organic matter is mediated by quality and quantity of crop residues: Mechanisms and thresholds. Biol. Fertil. Soils 2017, 53, 287-301. [CrossRef]

54. Han, S.; Zeng, L.Y.; Luo, X.S.; Xiong, X.; Wen, S.L.; Wang, B.R. Shifts in Nitrobacter- and Nitrospira-like nitrite-oxidizing bacterial communities under long-term fertilization practices. Soil Biol. Biochem. 2018, 124, 118-125. [CrossRef]

55. Ahn, J.H.; Song, J.; Kim, B.Y.; Kim, M.S.; Joa, J.H.; Weon, H.Y. Characterization of the Bacterial and Archaeal Communities in Rice Field Soils Subjected to Long-Term Fertilization Practices. J. Microbiol. 2012, 50, 754-765. [CrossRef]

56. Gupta, R.S. The phylogeny of proteobacteria: Relationships to other eubacterial phyla and eukaryotes. FEMS Microbiol. Rev. 2000, 24, 367-402. [CrossRef]

57. Yi, W.J.; You, J.H.; Zhu, C.; Wang, B.L.; Qu, D. Diversity, dynamic and abundance of Geobacteraceae species in paddy soil following slurry incubation. Eur. J. Soil Biol. 2013, 56, 11-18. [CrossRef]

58. Wisawapipat, W.; Chooaiem, N.; Aramrak, S.; Chittamart, N.; Nookabkaew, S.; Rangkadilok, N. Sulfur amendments to soil decrease inorganic arsenic accumulation in rice grain under flooded and nonflooded conditions: Insights from temporal dynamics of porewater chemistry and solid-phase arsenic solubility. Sci. Total Environ. 2021, 779, 146352. [CrossRef] [PubMed]

59. Yuan, C.L.; Na, S.; Li, F.B.; Hu, H.W. Impact of sulfate and iron oxide on bacterial community dynamics in paddy soil under alternate watering conditions. J. Hazard. Mater. 2021, 408, 124417. [CrossRef] [PubMed]

60. Wolinska, A.; Kuzniar, A.; Zielenkiewicz, U.; Izak, D.; Szafranek-Nakonieczna, A.; Banach, A. Bacteroidetes as a sensitive biological indicator of agricultural soil usage revealed by a culture-independent approach. Appl. Soil Ecol. 2017, 119, 128-137. [CrossRef]

61. Lydell, C.; Dowell, L.; Sikaroodi, M.; Gillevet, P.; Emerson, D. A population survey of members of the phylum Bacteroidetes isolated from salt marsh sediments along the East Coast of the United States. Microb. Ecol. 2004, 48, 263-273. [CrossRef]

62. Jangid, K.; Williams, M.A.; Franzluebbers, A.J.; Sanderlin, J.S.; Reeves, J.H.; Jenkins, M.B. Relative impacts of land-use, management intensity and fertilization upon soil microbial community structure in agricultural systems. Soil Biol. Biochem. 2008, 40, 2843-2853. [CrossRef]

63. Konishi, M.; Homma, Y.; Kubonouchi, M.; Kato, Y. Agent Used for Promoting Growth of Plant e.g., Tomato, Comprises Microorganism Contained in Bacteroidetes, Microorganism Contained in Chloroflexi, Microorganism Contained in Gemmatimonadetes, and Microorganisms contained in Verrucomicrobia. 2020. Available online: http://apps.webofknowledge.com/full_record. do?colName=DIIDW\&recordID=202088488Q\&log_event=no\&search_mode=GeneralSearch\&qid=1\&log_event=yes\&product=

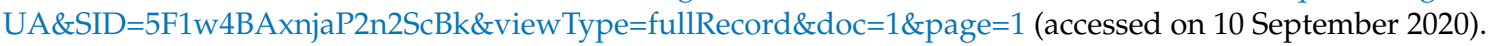

64. Raio, A.; Puopolo, G. Pseudomonas chlororaphis metabolites as biocontrol promoters of plant health and improved crop yield. World J. Microbiol. Biotechnol. 2021, 37, 99. [CrossRef]

65. Fiori, A.C.G.; Schwan-Estrada, K.R.F.; Stangarlin, J.R.; Vida, J.B.; Scapim, C.A.; Cruz, M.E.S. Antifungal activity of leaf extracts and essential oils of some medicinal plants against Didymella bryoniae. J. Phytopathol. 2000, 148, 483-487. [CrossRef]

66. Wei, X.; Wang, X.; Cao, P.; Gao, Z.; Chen, A.J.; Han, J. Microbial Community Changes in the Rhizosphere Soil of Healthy and Rusty Panax ginseng and Discovery of Pivotal Fungal Genera Associated with Rusty Roots. Biomed. Res. Int. 2020, 2020 , 8018525. [CrossRef] [PubMed]

67. Shi, S.; Nuccio, E.E.; Shi, Z.J.; He, Z.; Zhou, J.; Firestone, M.K. The interconnected rhizosphere: High network complexity dominates rhizosphere assemblages. Ecol. Lett. 2016, 19, 926-936. [CrossRef] [PubMed]

68. Montoya, J.M.; Pimm, S.L.; Sole, R.V. Ecological networks and their fragility. Nature 2006, 442, 259-264. [CrossRef]

69. Xiao, X.; Liang, Y.T.; Zhou, S.; Zhuang, S.Y.; Sun, B. Fungal community reveals less dispersal limitation and potentially more connected network than that of bacteria in bamboo forest soils. Mol. Ecol. 2018, 27, 550-563. [CrossRef]

70. Zhang, B.G.; Zhang, J.; Liu, Y.; Shi, P.; Wei, G.H. Co-occurrence patterns of soybean rhizosphere microbiome at a continental scale. Soil Biol. Biochem. 2018, 118, 178-186. [CrossRef]

71. Berry, D.; Widder, S. Deciphering microbial interactions and detecting keystone species with co-occurrence networks. Front. Microbiol. 2014. [CrossRef] [PubMed] 